\title{
The Axon Initial Segment: An Updated Viewpoint
}

\author{
(C) Christophe Leterrier \\ NeuroCyto, INP UMR7051, Aix Marseille Université, CNRS, 13344 cedex 15, Marseille, France
}

At the base of axons sits a unique compartment called the axon initial segment (AIS). The AIS generates and shapes the action potential before it is propagated along the axon. Neuronal excitability thus depends crucially on the AIS composition and position, and these adapt to developmental and physiological conditions. The AIS also demarcates the boundary between the somatodendritic and axonal compartments. Recent studies have brought insights into the molecular architecture of the AIS and how it regulates protein trafficking. This Viewpoints article summarizes current knowledge about the AIS and highlights future challenges in understanding this key actor of neuronal physiology.

\section{Introduction}

Neurons ensure the directional propagation of signals throughout the nervous system. The functional asymmetry of neurons is supported by cellular compartmentation: the cell body and dendrites (somatodendritic compartment) receive synaptic inputs, and the axon propagates the action potentials that trigger synaptic release toward target cells. Between the cell body and the axon sits a unique compartment called the axon initial segment (AIS). The AIS was first described 50 years ago (Palay et al., 1968), and its molecular composition and organization have been progressively elucidated during the following decades (Rasband, 2010a). Studies have delineated the mechanisms driving its formation and maintenance, as well as its modification in different physiological and pathological contexts (Grubb et al., 2011; Petersen et al., 2016; Yamada and Kuba, 2016). Recent years have also brought crucial insights into the functions of the AIS: how ion channels at its surface generate and shape the action potential (Clark et al., 2009; Kole and Stuart, 2012), and how its specialized scaffold regulates protein trafficking between the cell body and the axon (Leterrier and Dargent, 2014; Nirschl et al., 2017).

This Viewpoints article aims to provide an up-to-date summary of these aspects, familiarizing nonspecialists with this unique neuronal compartment and reviewing the latest results in this actively evolving field. Numerous, likely subjective, choices have been made to keep this Viewpoints article short and synoptic, and the interested reader will find additional details in several recent reviews (Jones and Svitkina, 2016; Leterrier, 2016; Zhang and Rasband, 2016; Nelson and Jenkins, 2017).

\section{Overview of the AIS architecture}

In most neurons, the AIS is present along the first $20-60 \mu \mathrm{m}$ of the axon shaft (Fig. 1). The AIS usually starts just after the axon

\footnotetext{
Received Dec. 3, 2017; revised Jan. 20, 2018; accepted Jan. 25, 2018.

I thank Amélie Fréal for stimulating discussions; and Subhojit Roy and Marie-Jeanne Papandréou for feedback on the manuscript.

The author declares no competing financial interests.

Correspondence should be addressed to Dr. Christophe Leterrier, NeuroCyto, INP UMR7051, Aix Marseille Université, CNRS, 13344 cedex 15, Marseille, France. E-mail: christophe.leterrier@univ-amu.fr.

DOI:10.1523/JNEUROSCI.1922-17.2018

Copyright $\odot 2018$ the authors $\quad 0270-6474 / 18 / 382135-11 \$ 15.00 / 0$
}

hillock close to the cell body, but sometimes more distally, for example, when the axon emerges as a branch from a proximal dendrite (Thome et al., 2014; Höfflin et al., 2017). In electron microscopy studies, the AIS was initially defined by three unique morphological features: closely apposed bundles of 3-10 microtubules called fascicles, a $\sim 50$-nm-thick undercoat lining the plasma membrane, and an almost complete absence of ribosomes (Palay et al., 1968; Peters et al., 1968). In some neuron types, the AIS also contains postsynaptic specializations connected to GABAergic interneurons (Jones and Powell, 1969; Kosaka, 1980).

At the molecular level, AIS proteins organize as a layered scaffold spanning from microtubules to the plasma membrane (Leterrier, 2016). The central component of this scaffold is ankyrin $G$ (ANK3), with long isoforms of 480 and $270 \mathrm{kDa}$ that concentrate specifically at the AIS and nodes of Ranvier (Kordeli et al., 1995). Ankyrin $G$ has a modular structure, allowing it to organize the AIS scaffold, with a membrane-binding domain (made of 24 ankyrin repeats), and spectrin-binding, serine-rich, tail and carboxyterminal domains (Fig. 2A) (Bennett and Lorenzo, 2013). The aminoterminal side of ankyrin $\mathrm{G}$ is inserted into the actin/ spectrin submembrane scaffold. It anchors AIS-specific membrane proteins, including voltage gated sodium (Nav) and potassium $(\mathrm{Kv})$ channels and two cell adhesion molecules (CAMs): the $186 \mathrm{kDa}$ isoform of neurofascin 186 (NF-186) and NrCAM (Davis et al., 1996). The ankyrin G carboxyterminal side connects this submembrane scaffold to microtubules via interactions with microtubule-associated proteins, such as EB1/3 and Ndel1 (Leterrier et al., 2011; Kuijpers et al., 2016).

\section{The actin/spectrin submembrane scaffold and the formation} of the AIS

The actin/spectrin submembrane complex is present along the whole axonal plasma membrane (or axolemma). In the AIS and nodes of Ranvier, spectrin tetramers contain the $\beta 4$-spectrin subunit (Fig. 2B) (Berghs et al., 2000). The full-length, $280 \mathrm{kDa}$ isoform of $\beta 4$-spectrin $\left(\beta 4 \sum 1\right)$ contains an actin-binding calponin-homology domain, 17 triple-helical spectrin repeats, and a specific pleckstrin-homology domain (Bennett and Lorenzo, 2013). A shorter, $140 \mathrm{kDa} \beta 4 \sum 6$ isoform lacks the actin-binding domains and repeats 1-9 (Komada and Soriano, 2002). This 

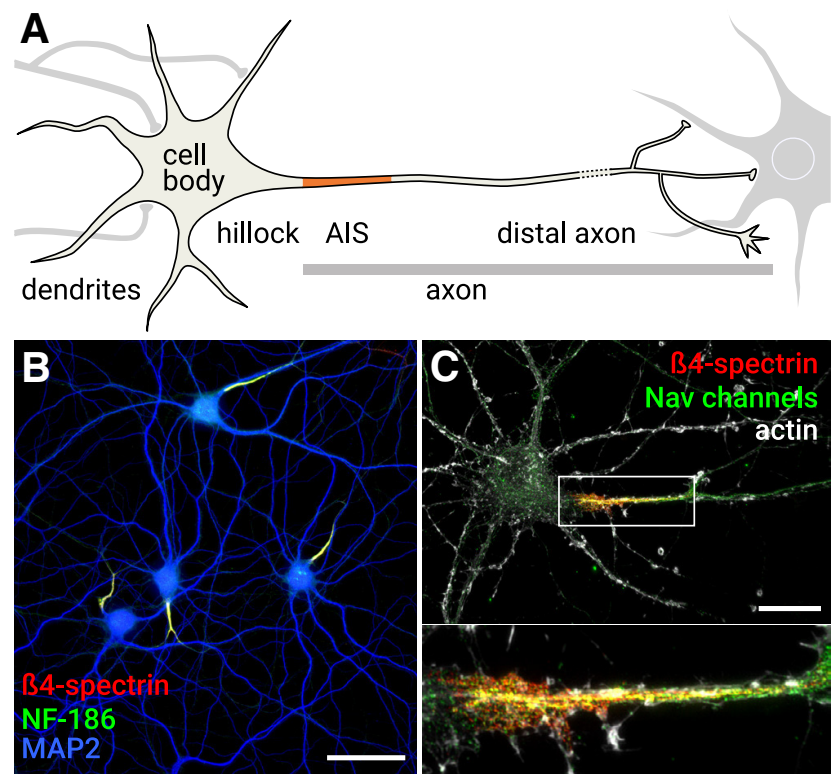

Figure 1. The AIS. A, A typical neuron receives input on the cell body and dendrites (left). The hillock leads to the axon, which contains the AIS (orange). The distal axon contacts downstream neurons (right). $\boldsymbol{B}$, Hippocampal neurons after $22 \mathrm{~d}$ in culture labeled for the AIS components NF-186 (green) and $\beta 4$-spectrin (red). The somatodendritic compartment is labeled using an anti-MAP2 antibody (blue). Scale bar, $50 \mu \mathrm{m}$. C, Hippocampal neuron after $14 \mathrm{~d}$ in culture labeled for actin (gray), $\beta 4$-spectrin (red), and Nav channels (green). Bottom, The zoomed image represents the AIS. Scale bar, $20 \mu \mathrm{m}$.

shorter isoform becomes progressively enriched as the AIS matures (Yoshimura et al., 2016). Spectrins are head-to-head tetramers composed of two $\alpha$ and two $\beta$ subunits (Fig. 2B). The $\alpha 2$-spectrin subunit, expressed throughout neurons, has recently been identified as the $\alpha$-spectrin partner of $\beta 4$-spectrin at the AIS and nodes of Ranvier (Huang et al., 2017a, b). Interaction with ankyrin $G$ drives the concentration of $\beta 4$-spectrin at the AIS (Dzhashiashvili et al., 2007; Yang et al., 2007). Spectrin repeats $14-15$ of $\beta 4$-spectrin bind to the ankyrin $G$ spectrin-binding domain (Komada and Soriano, 2002). A second site in the tail of the $480 \mathrm{kDa}$ ankyrin $\mathrm{G}$ is also implicated in its recruitment at the AIS (Jenkins et al., 2015).

Using super-resolution microscopy, the actin/spectrin submembrane complex in axons was shown to be periodically organized with actin rings connected by tetramers of spectrin (Figs. 2C, 3A) (Xu et al., 2013; D'Este et al., 2015; Leterrier et al., 2015). This periodic scaffold is composed of actin and tetramers of $\alpha 2$ and $\beta 4$-spectrin at the AIS, while $\beta 2$-spectrin replaces $\beta 4$ spectrin along the distal axon (Zhong et al., 2014; Huang et al., $2017 \mathrm{a}$ ). The $\sim 190 \mathrm{~nm}$ distance between actin rings, just below the $\sim 250 \mathrm{~nm}$ diffraction limit of epifluorescence microscopy, corresponds to the length of individual spectrin tetramers (Bennett et al., 1982). Indeed, spectrin tetramers connect adjacent actin rings: the aminotermini of the two $\beta$-spectrin subunits colocalize with actin rings, whereas their carboxytermini and the two aminotermini of $\alpha 2$-spectrin are found halfway between rings (Fig. 2C) (Zhong et al., 2014; Huang et al., 2017a). In the AIS, ankyrin $\mathrm{G}$ binds to the center of the spectrin tetramer, thus positioning the ankyrin G/channels/CAMs complex midway between actin rings (Xu et al., 2013; Leterrier et al., 2015; D'Este et al., 2017). In the more distal axon, the periodic complex contains $\alpha 2 / \beta 2$ spectrin and anchors ankyrin $B$ rather than ankyrin $G$ between the actin rings (Xu et al., 2013; Zhong et al., 2014). The periodic actin/spectrin scaffold is crucial for the robustness of axons, help-
A
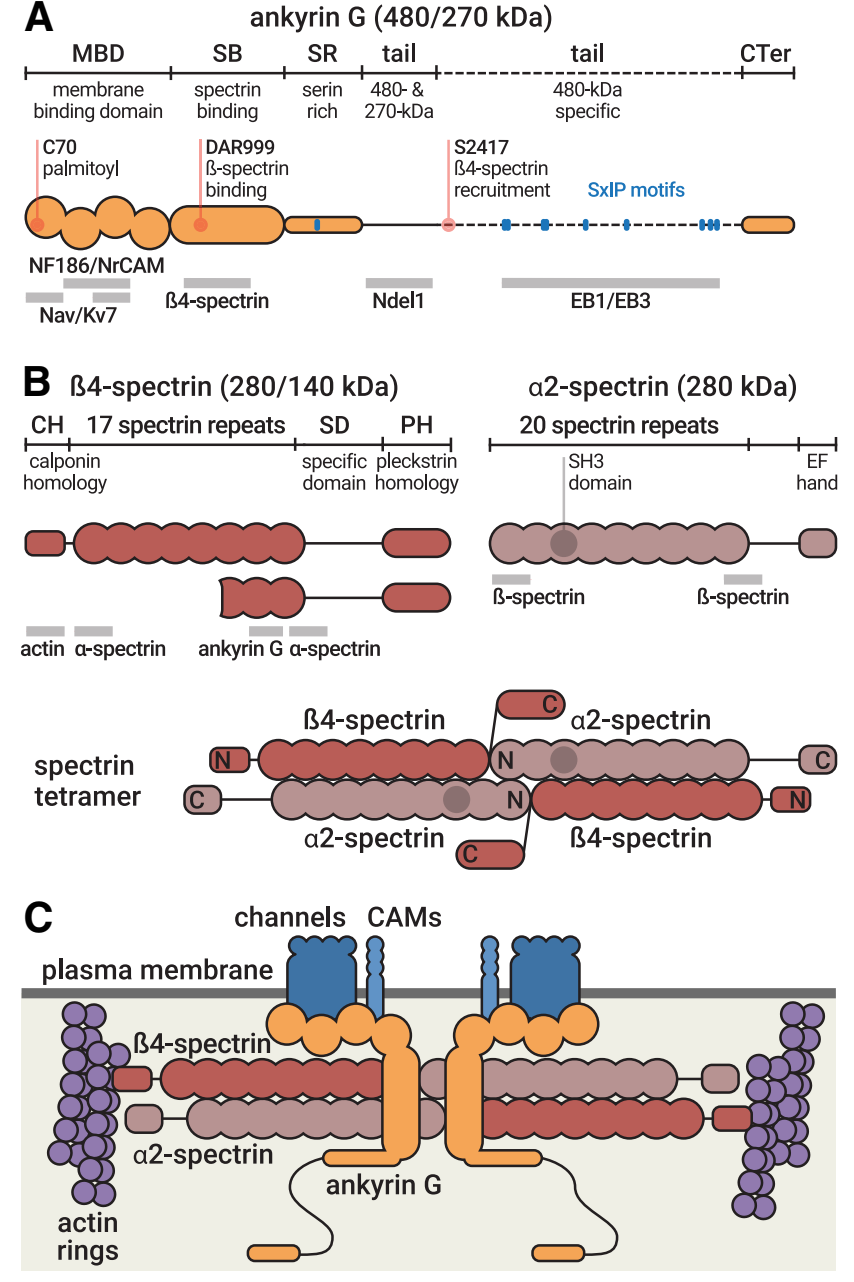

Figure 2. Molecular structure of ankyrin $G$ and AIS spectrins. $\boldsymbol{A}$, Domain organization of ankyrin $\mathrm{G}$, which exists as isoforms of 480 and $270 \mathrm{kDa}$ at the AIS (top, orange). Important residues (red) and EB-binding SxIP motifs (blue) are indicated. Binding sites of partners are indicated below the protein (gray bars). $\boldsymbol{B}$, Domain organization of $\beta 4$-spectrin, which exists as isoforms of 280 and $140 \mathrm{kDa}$ (left), and domain organization of $\alpha 2$-spectrin (right). Binding sites of partners are indicated below the protein (gray bars). Bottom, Structure of the $\alpha 2 / \beta 4$ spectrin tetramer. $\mathrm{N}$ and $\mathrm{C}$ indicate the aminoterminus and carboxyterminus, respectively, of each subunit. C, The AIS submembrane complex. The $\alpha 2 / \beta 4$ spectrin tetramers (red) lie horizontally under the plasma membrane (dark gray), connecting actin rings (purple) with a distance of $\sim 190 \mathrm{~nm}$. In the middle of the tetramer, ankyrin $\mathrm{G}$ (orange) is bound to $\beta 4$-spectrin and anchors AIS membrane proteins (Nav/Kv7 channels, CAMs, blue).

ing them flex and resist mechanical constraints (Krieg et al., 2014, 2017; Zhang et al., 2017). The resulting periodic organization of Nav and Kv channels (Xu et al., 2013; Leterrier et al., 2015) could also affect action potential generation and conduction, although this has yet to be demonstrated.

The periodic actin/spectrin scaffold appears just after axonal specification, before the assembly of the AIS (Zhong et al., 2014); this shines a new light on the timing and hierarchy of component recruitment during AIS formation. Ankyrin G clusters along the proximal axon early during development: after 3-4 d in neuronal cultures, and between embryonic day 13.5 and postnatal day 1 in vivo depending on the neuronal type (Galiano et al., 2012; Gutzmann et al., 2014; Le Bras et al., 2014). Ankyrin G then recruits other AIS components: ion channels, CAMs, and $\beta 4$-spectrin (Zhou et al., 1998; Jenkins and Bennett, 2001; Hedstrom et al., 2007). The full-length $480 \mathrm{kDa}$ ankyrin $\mathrm{G}$ is necessary for this recruitment and the formation of the AIS, whereas the role of the 

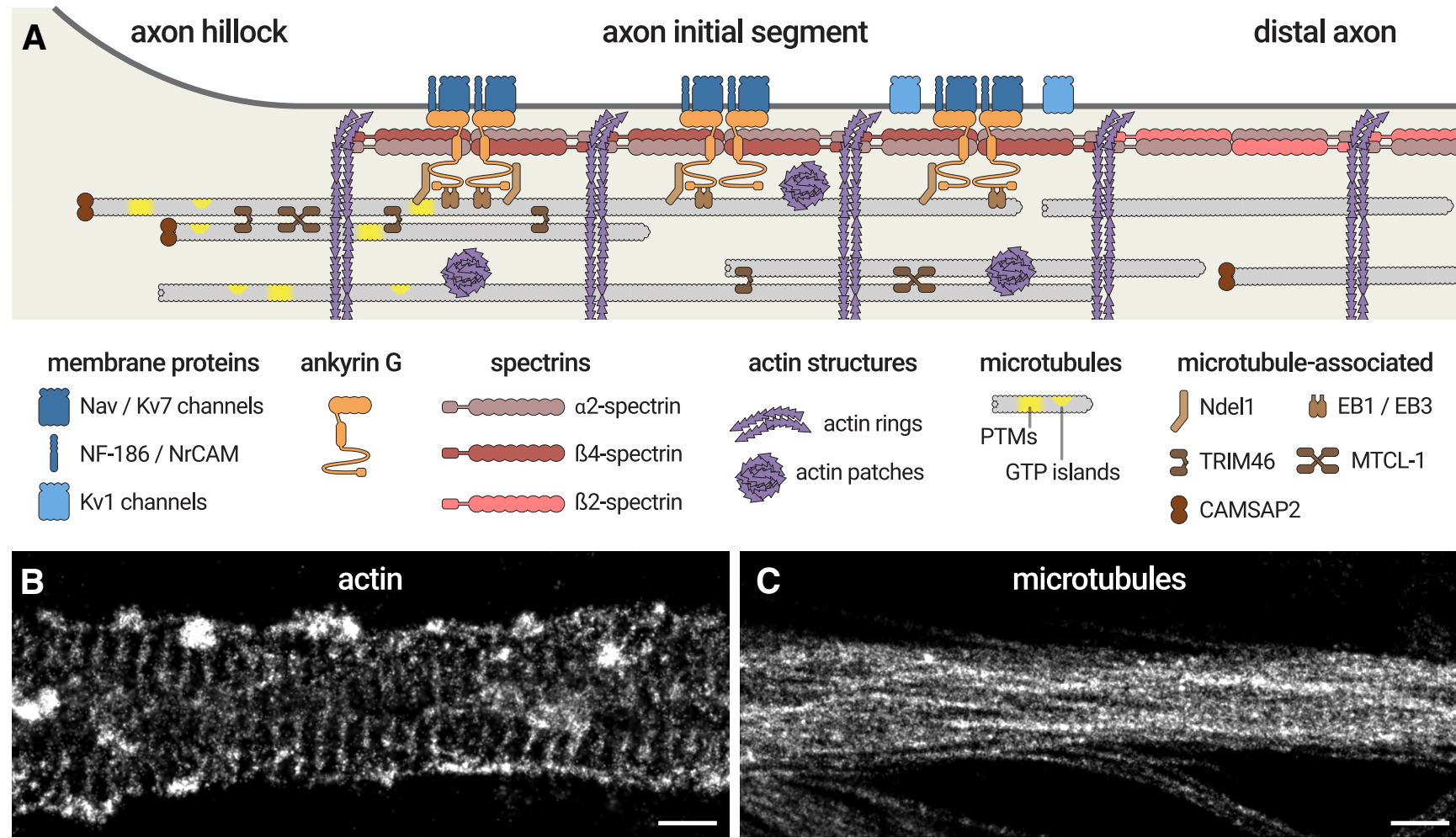

Figure 3. The molecular organization of the AIS.A, Diagram depicting the organization of the AIS scaffold. Membrane proteins (Nav/Kv7 channels, NF-186, NrCAM, blue) are anchored by ankyrin $\mathrm{G}$ (orange), itself inserted into the $\alpha 2 / \beta 4$-spectrin complex (red) that spaces actin rings (purple). Kv1 channels (light blue) are present along the distal AIS. In the distal axon, the complex is made of $\alpha 2$ - and $\beta 2$-spectrin (pink). Ankyrin $\mathrm{G}$ binds to microtubules via EB1/EB3 proteins and Ndel1 (brown). AIS microtubules (gray) are capped by CAMSAP2 at their minus-end (brown) and grouped in fascicles crosslinked by TRIM46 and possibly MTCL-1 (brown). They are enriched in post-translational modifications (PTMs) and GTP islands (yellow). Intracellular patches of actin (purple) are also present inside the AIS. $\boldsymbol{B}$, The $<50 \mathrm{~nm}$ resolution of stochastic optical reconstruction microscopy (STORM) makes it possible to resolve the $190 \mathrm{~nm}$ spacing of actin rings and the presence of actin patches along the AIS. C, STORM can resolve microtubule bundles along the AIS, but the close apposition within bundles ( $\sim 30 \mathrm{~nm}$ spacing) makes it a challenge to distinguish individual microtubules. Scale bars: $B, C, 0.5 \mu \mathrm{m}$.

shorter $270 \mathrm{kDa}$ isoform is less clear (Fig. 2A) (Jenkins et al., 2015; Fréal et al., 2016). Binding of ankyrin $\mathrm{G}$ to the plasma membrane, via membrane protein partners or palmitoylation of its membrane-binding domain, promotes its recruitment and stability at the AIS (He et al., 2012; Leterrier et al., 2017a). In cortical neurons, the clustering of ankyrin $G$ occurs after ankyrin B and $\beta 2$-spectrin assembly along the distal axon, directing the subsequent anchoring of the ankyrin $\mathrm{G} / \beta 4$-spectrin complex along the remaining proximal axon submembrane (Galiano et al., 2012; Normand and Rasband, 2015). In another study, the actin/ $\beta 2$ spectrin periodic scaffold was shown to assemble along the proximal axon after only $2 \mathrm{~d}$ in vitro and was not found along the distal axon until later stages (Zhong et al., 2014). This presence of the actin/ $\beta 2$-spectrin scaffold before the appearance of ankyrin $G$ at the nascent AIS suggests that $\beta 2$-spectrin could be later replaced or supplemented by $\beta 4$-spectrin within the periodic scaffold (Zhong et al., 2014). An interplay between $\beta 2$-spectrin and ankyrin G could thus be an early event of AIS formation, but the exact hierarchical and temporal sequence remains to be established.

\section{Ion channels at the AIS}

Ankyrin G recruits and anchors ion channels (Nav, Kv7) and CAMs (NF-186, NrCAM) via several binding sites in its membrane-binding domain (Wang et al., 2014). Ankyrin G binds to an interaction motif within the II-III intracellular loop of Nav channels (Srinivasan et al., 1988; Garrido et al., 2003; Lemaillet et al., 2003; Gasser et al., 2012). This results in an $\sim 30$-fold concen- tration of Nav channels in the AIS compared with in the dendrites or distal axon (Kole et al., 2008; Lorincz and Nusser, 2010). The Nav channel composition of the AIS depends on the developmental stage and on the neuronal type, with Nav1.6 being the dominant type in mature neurons (Inda et al., 2006; Van Wart et al., 2007; Lorincz and Nusser, 2008; Duménieu et al., 2017). Nav channels are primarily responsible for the initiation of action potentials at the AIS (Clark et al., 2009; Kole and Stuart, 2012). The pore-forming $\mathrm{Nav} \alpha$ is often associated with $\mathrm{Nav} \beta$ subunits, with a reported AIS concentration of Nav $\beta 1$ and Nav $\beta 4$ (Hull and Isom, 2017), and they are regulated by fibroblast growth factor homologs FHF1-4/FGF12-14 (Dover et al., 2016; Pablo et al., 2016).

Voltage-gated potassium $(\mathrm{Kv})$ channels are also present at the AIS, forming distinct complexes. Kv7.2 and Kv7.3 channels (KCNQ2/KCNQ3) concentrate at the AIS by binding to ankyrin G through a Nav-homologous motif in their carboxyterminal tail (Pan et al., 2006; Cooper, 2011; Xu and Cooper, 2015). They generate the M current that restricts intrinsic firing and excitability (Shah et al., 2008). Kv1.1 and Kv1.2 associate with PSD-93, Caspr2, Tag1, and ADAM22 at the AIS (Ogawa et al., 2008), where they modulate action potential firing and waveform (Kole et al., 2007). This complex is not bound to ankyrin G, and how it localizes at the AIS remains unclear (Rasband, 2010b). Interestingly, Kv1.2 channels cluster at actin rings, rather than in-between them (D'Este et al., 2017). Kv2.1 channels are also found at the AIS, where they form distinct, large ankyrin G-negative clusters (Sarmiere et al., 2008; King et al., 2014; Jensen et al., 2017). 
Several mechanisms underlie the targeting of ion channels to the AIS (Leterrier et al., 2010). Chimera constructs bearing the Nav1.2 ankyrin-binding motif are delivered nonspecifically to the plasma membrane in all compartments, then are selectively endocytosed in the cell body, dendrites, and distal axon, leaving only those in the AIS (Fache et al., 2004). This "negative" targeting likely happens during the dynamic phase of AIS formation. At later stages, a direct insertion of Nav channels occurs at the assembled AIS (Akin et al., 2015), cotransported with ankyrin G (Barry et al., 2014; Leterrier et al., 2017a). Kv1 channels are targeted to the axon and the AIS through association of the $\mathrm{Kv} \beta 2$ subunit with the microtubule end-binding protein EB1 and kinesin-2 (Vacher et al., 2011), and a Golgi-independent pathway directs a specific fraction of Kv2.1 channels to the AIS (Jensen et al., 2017).

Once channels are anchored at the AIS, their diffusion and turnover are limited (Angelides et al., 1988; Brachet et al., 2010; Akin et al., 2015; Benned-Jensen et al., 2016). Although they are not required for AIS formation (Dzhashiashvili et al., 2007; Hedstrom et al., 2007; but see Xu and Shrager, 2005), depletion of ion channels and CAMs affects the integrity of the assembled AIS (Zonta et al., 2011; Leterrier et al., 2017a). A key feature of the assembled AIS scaffold is thus the interdependence between components, a feature that could facilitate its plasticity.

\section{Links between the AIS scaffold and microtubules}

While the aminoterminus of ankyrin G is inserted in the actin/ spectrin submembrane scaffold, anchoring ion channels and CAMs, its carboxyterminal side extends $\sim 35 \mathrm{~nm}$ toward the cytoplasm (Fig. 3A) (Leterrier et al., 2015). The numerous SxIP motifs present in the tail domain of ankyrin G (Fig. 2A) allow binding to microtubules via EB1 and EB3 proteins (Fréal et al., 2016). In contrast to their classical role as microtubules plus-end organizers (van de Willige et al., 2016), EBs concentrate along the microtubule lattice at the AIS (Nakata and Hirokawa, 2003; Leterrier et al., 2011). The interplay between EBs and ankyrin G is necessary for both the formation and maintenance of the AIS scaffold (Leterrier et al., 2011; Fréal et al., 2016). The recruitment of microtubules $\sim 50-100 \mathrm{~nm}$ under the plasma membrane by ankyrin $\mathrm{G}$ and $\mathrm{EBs}$ could be important for organizing trafficking into the axon (see below).

Axonal microtubules have a uniform orientation with their plus-ends toward the axon tip (Fig. 3A) (Baas and Lin, 2011; Yau et al., 2016). In the AIS, they are grouped in fascicles, a feature that depends on ankyrin G (Fig. 3B) (Sobotzik et al., 2009). This unique organization depends on the presence of several microtubule-associated proteins (MAPs) that have been recently identified at the AIS. CAMSAP2, a member of the CAMSAP/patronin minus-end binding protein family (Akhmanova and Hoogenraad, 2015), is present at the axon hillock (just before the AIS) and is important for the establishing uniform orientation of microtubules in the axon (Yau et al., 2014). TRIM46 is associated with proximal AIS microtubules, and it is important for axon specification, uniform microtubule orientation, and AIS assembly. Its microtubule-bundling activity could drive the formation of microtubule fascicles (van Beuningen et al., 2015). Another microtubule-associated protein, MTCL-1, also associates with microtubules within the proximal AIS and has a stabilizing role (Satake et al., 2017).

The biochemical characteristics of microtubules at the AIS are also unique (Fig. $3 A$ ). They are rich in post-translational modifications (Janke, 2014), such as tubulin acetylation, detyrosination, and polyglutamylation (Konishi and Setou, 2009; Hammond et al., 2010; Tapia et al., 2010). These modifications progressively accumulate as the microtubules age, which is consistent with the observed stability of AIS microtubules (Baas et al., 1993; Hammond et al., 2010; but see Zempel et al., 2017). Microtubules polymerize from GTP-tubulin, but the GTP is rapidly hydrolyzed into GDP after assembly, leaving only a short cap of GTP-tubulin at the growing microtubule tip (Brouhard, 2015). However, short stretches of GTP-tubulin can be found along the microtubule lattice; these either remain after tip assembly (Dimitrov et al., 2008) or are formed later by in-lattice microtubule repair (Aumeier et al., 2016). These GTP islands are abundant along the axon hillock and AIS (Nakata et al., 2011), and they might participate in EB accumulation, given that EB1 and EB3 have a preferential affinity for GTP-tubulin (Maurer et al., 2012).

\section{The AIS as the gatekeeper of axonal identity}

Depletion of ankyrin G, by shRNA or gene knock-out, has a profound effect on the proximal axon composition: AIS components are not recruited (Zhou et al., 1998; Jenkins and Bennett, 2001; Hedstrom et al., 2007) or lose their localization (Hedstrom et al., 2008; Leterrier et al., 2017a). Moreover, the proximal axon of ankyrin G-depleted neurons is progressively invaded by somatodendritic-specific proteins, such as MAP2, KCC2, and integrin $\beta 1$ (Hedstrom et al., 2008; Franssen et al., 2015; Jenkins et al., 2015), and ectopic spines containing excitatory postsynaptic components form along the AIS (Hedstrom et al., 2008; Sobotzik et al., 2009). Thus, the AIS acts as a boundary between the somatodendritic and axonal compartments and maintains the distinct molecular identity of the axon (Rasband, 2010a). Two processes potentially contribute to this role: a surface diffusion barrier segregating the somatodendritic and axonal membrane proteins and an intracellular filter regulating vesicular transport as well as cytosolic diffusion between the cell body and the axon (Leterrier and Dargent, 2014; Huang and Rasband, 2016; Nirschl et al., 2017).

\section{The AIS diffusion barrier}

The high concentration of membrane proteins anchored at the AIS (Matsumoto and Rosenbluth, 1985) was proposed to create an AIS "barrier" maintaining the distinct composition between the somatodendritic and axonal plasma membrane (Dotti and Simons, 1990). Indeed, ankyrin G-bound channels and CAMs are strongly immobilized at the AIS (Nakada et al., 2003; Boiko et al., 2007; Brachet et al., 2010), and membrane protein diffusion through the AIS is restricted (Fig. 4A) (Winckler et al., 1999). Membrane lipids only slowly diffuse between the cell body and axon (Kobayashi et al., 1992), and single particle tracking shows that they are less mobile at the AIS than in the cell body or the more distal axon surface (Nakada et al., 2003). These findings led to the "picket and fences" model of the AIS diffusion barrier: diffusion of membrane proteins and lipids is hampered by picket membrane proteins (channels and CAMs) bound to submembrane fences (ankyrin G/spectrin/actin scaffold) (Nakada et al., 2003).

How does the "pickets and fences" model accommodate the periodic alternation of actin rings and ankyrin G/membraneprotein complexes spaced along spectrin tetramers (Xu et al., 2013)? Surprisingly, submembrane actin rings, rather than the ankyrin G/membrane-proteins complex, seem to compartment the diffusion of a membrane-bound probe along the AIS (Fig. 4A) (Albrecht et al., 2016). A possible explanation is that the "pickets" formed by ankyrin-bound membrane proteins restrict diffusion not by excluding the passage of membrane components, but by capturing and slowing them down within a dense 
A
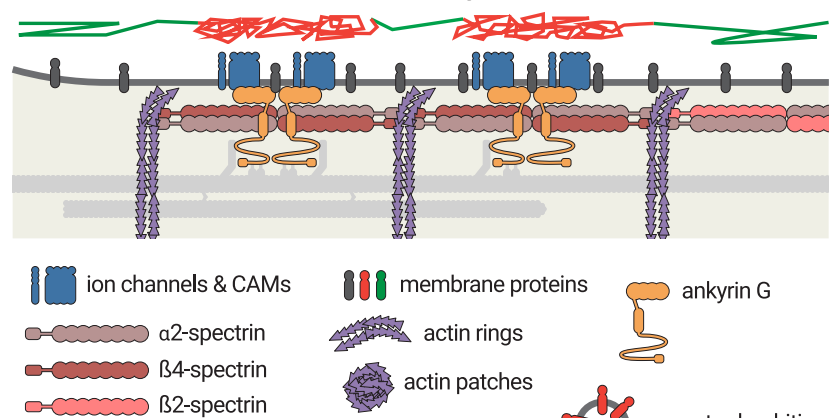

Q-cimon B2-spectrin

Eminum microtubules

PTMs GTP islands
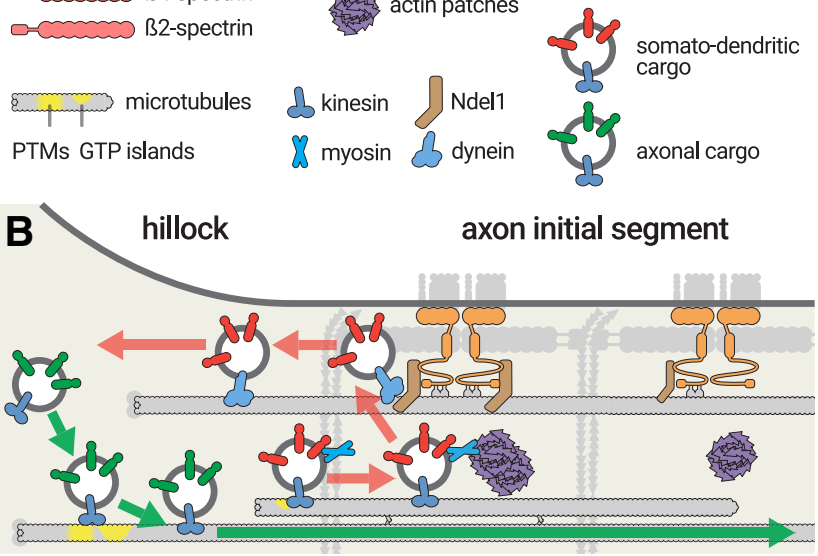

Figure 4. Protein trafficking at the AIS. $A$, The AIS forms a diffusion barrier for membrane proteins and lipids (gray). A virtual trajectory (top) shows unimpaired diffusion at the cell body and distal axon (green segments), whereas diffusion at the AIS is limited by the AIS scaffold (red segments). $\boldsymbol{B}$, Sorting of transport vesicles at the AIS entrance. Vesicles containing axonal cargoes (green) have kinesin motors (blue) that recognize cues on microtubules entering the axon, either post-translational modifications or GTP islands (yellow), before being transported into the axon (green arrow). Somatodendritic cargoes that start progressing into the AIS (red) are stopped by myosin-mediated immobilization at actin patches, before being brought back to the cell body by Ndel1-dependendant dynein transport (red arrows).

"forest," similar to what was proposed at the postsynaptic membrane (Renner et al., 2009; Li and Blanpied, 2016). This would also explain why surface diffusion is not affected in the axon shaft beyond the AIS, as it lacks the dense array of ankyrin/spectrinbound membrane proteins.

\section{Sorting of intracellular trafficking at the AIS}

The regulation of intracellular trafficking at the AIS has been hotly debated since it was initially proposed (Song et al., 2009). Intracellular trafficking includes diffusion of soluble macromolecules through the AIS axoplasm and active vesicular transport of membranous organelles and vesicles. Regarding the former, an actin-based cytoplasmic sieve has been proposed to impede diffusion between the cell body and the axon, with a mesh size estimated at $13 \mathrm{~nm}$ (Song et al., 2009; Sun et al., 2014). However, fluorescence and electron microscopy do not show a dense accumulation of actin inside the AIS: actin forms rings connected by spectrin, as in the rest of the axon (Xu et al., 2013; Leterrier et al., 2015; D'Este et al., 2017), as well as patches made of short intertwined filaments (Fig. $3 A, B$ ) (Watanabe et al., 2012; Jones et al., 2014; Leterrier et al., 2017b). Diffusion of the microtubuleassociated protein tau is impaired at the AIS in an isoformdependent manner (Li et al., 2011; Zempel et al., 2017). Altogether the mechanisms of soluble protein diffusion at the AIS are still unclear; studies using controlled assays could bring more clarity, as they did for diffusion in the primary cilium (Breslow et al., 2013; Lin et al., 2013).
Vesicular transport through the AIS has long attracted interest, as regulating the entry of cargoes into the axon could have a crucial effect on the establishment and maintenance of polarity (Rasband, 2010a; Bentley and Banker, 2016). Vesicles containing axonal membrane proteins are assembled in the cell body and preferentially trafficked into the axon, with no visible slowing at the AIS (Petersen et al., 2014; Jenkins et al., 2015; Liu et al., 2018), whereas vesicles harboring somatodendritic proteins are excluded from entering the axon, or stall and reverse within the AIS when they do (Burack et al., 2000; Al-Bassam et al., 2012; Petersen et al., 2014). This suggests that a specific sorting process occurs at the AIS entrance (Fig. 4B). A handful of recent studies point to a two-stage mechanism for vesicle recruitment and sorting: (1) direct recruitment or exclusion at the AIS entrance and (2) retrieval of mistargeted cargos within the AIS (Nirschl et al., 2017). Recruitment of axonal vesicles and exclusion of somatodendritic cargoes occurs within the axon hillock at the AIS entrance, a region recently termed "pre-axonal exclusion zone" (Fig. 4B) (Farías et al., 2015). This region overlaps with the TRIM46positive region that depends on ankyrin $\mathrm{G}$ for its proper assembly (van Beuningen et al., 2015). An interesting question is whether axonal cargo recruitment and somatodendritic cargo exclusion are independent of the ankyrin G-based AIS scaffold (Farías et al., 2015; Jenkins et al., 2015). In DRG neurons, that lack the concentration of AIS components, such as ankyrin G, this pre-axonal exclusion also occurs at the axon hillock via a TRIM46/MAP2 based mechanism (Gumy et al., 2017).

Vesicular transport is driven by motor proteins (kinesins, dynein), and the AIS might also regulate their recruitment to direct axonal trafficking. Because axonal microtubules have a uniform orientation with their plus-ends out, plus-end-directed motors (i.e., kinesins) drive anterograde transport from the cell body toward the axon tip (Kapitein and Hoogenraad, 2015). A subset of kinesins, most notably the kinesin-1 members KIF5A/B/C, selectively direct transport cargoes into the axon rather than dendrites (Nakata and Hirokawa, 2003; Huang and Banker, 2012; Lipka et al., 2016). The KIF5 motor head is able to recognize and selectively bind microtubules that enter the axon (Nakata and Hirokawa, 2003), but the cue it detects remains elusive. KIF5 could recognize distinct post-translational modifications on axonal microtubules (Konishi and Setou, 2009; Hammond et al., 2010; Tapia et al., 2010). Interestingly, stretches of GTP-tubulin ("GTP islands") found along microtubules in the AIS have been shown to recruit KIF5 (Nakata et al., 2011). Based on this, I propose a "repair and recruit loop" hypothesis of preferential KIF5 recruitment into the axon. As mentioned above, GTP islands were initially proposed to be remnants from GTP-tubulin polymerization at the microtubule plus tip (Dimitrov et al., 2008; Nakata et al., 2011), but they can instead result from repair of microtubule defects by the incorporation of GTP-tubulin into the lattice (Schaedel et al., 2015; Aumeier et al., 2016). Moreover, such defects might be created by the passage of kinesin motors, which can remove tubulin monomers as they walk along microtubules (Dumont et al., 2015). This would generate a feedback loop to establish preferential transport to the axon: the sustained procession of axonal kinesins induces numerous defects along AIS microtubules, which are subsequently repaired by GTPtubulin incorporation. This concentration of GTP-tubulin drives the recruitment of more kinesins, causing more defects, repair, and recruitment.

An additional sorting mechanism involving retrieval within the AIS ensures that somatodendritic cargoes are not mistargeted to the axon (Fig. 4B). Actin is involved in this process: the actin- 
based molecular motor myosin $\mathrm{V}$ interacts with binding motifs on somatodendritic proteins (Lewis et al., 2009) and immobilizes vesicles at actin patches within the AIS, preventing further transport (Watanabe et al., 2012; Balasanyan et al., 2017; Janssen et al., 2017). Ndel1, a regulator of the microtubule minus-end-directed motor complex dynein, is stably anchored at the AIS by its interaction with ankyrin $\mathrm{G}$ (Kuijpers et al., 2016). Ndel1, together with its partner LIS1, can activate dynein-mediated transport to retrieve vesicles stalled at the AIS, and this retrieval is regulated by cdk5-mediated phosphorylation of Ndel1 (Klinman et al., 2017). Another retrieval mechanism involves the activation of dynaminmediated retrograde transport by Rab5 and its effector FHF (Guo et al., 2016). Thus, AIS retrieval is likely to rely on actindependent immobilization followed by dynein-mediated retrograde transport to the cell body, but this sequence has not been directly demonstrated yet.

\section{Morphological plasticity at the AIS}

Despite its complex architecture and overall stability, the AIS morphology is finely regulated and can adapt to physiological or pathological cellular changes (Yoshimura and Rasband, 2014; Yamada and Kuba, 2016; Jamann et al., 2018). This includes short-term changes (seconds to minutes) due to channel modulation, or long-term changes (hours to days) implicating morphological changes (Petersen et al., 2016).

Fast inhibition of the AIS electrogenic properties is often linked to elevated intracellular calcium. Elevated activity leads to fast endocytosis of Nav and Kv7 channels from the AIS due to calcium entry via NMDA receptors (Benned-Jensen et al., 2016). Entry of calcium can also occur via $\mathrm{P} 2 \mathrm{X}$ receptors, downregulating sodium channel currents (Del Puerto et al., 2015), or via Cav3 channels to suppress the M-current driven by Kv7 channels (Martinello et al., 2015). Neuromodulatory transmitters can also regulate channel activity at the AIS. For example, dopamine can inhibit Cav3 channels (Bender et al., 2010; Yang et al., 2016), and serotonin, acting via 5-HT1A receptors, modulates Nav in cortical pyramidal neurons (Yin et al., 2017) and motoneurons (Cotel et al., 2013). Serotonin also modulates HCN channels near the AIS (Ko et al., 2016).

The AIS also exhibits long-term changes in morphology, with variations in length and position along the proximal axon (Yamada and Kuba, 2016). During development, the AIS shortens and densifies (Kuba et al., 2014; Le Bras et al., 2014) or lengthens (Galiano et al., 2012) depending on the neuronal type studied. The AIS is stably maintained with age in the rat hippocampus (Kneynsberg and Kanaan, 2017) but shortens in monkeys (Cruz et al., 2009). These variations allow intrinsic excitability to be tuned, and they are linked to the development of inputs: early-life interventions, such as sensory deprivation, can affect this morphological evolution (Gutzmann et al., 2014; Kuba et al., 2014; Nozari et al., 2017; Schlüter et al., 2017). In addition, extrinsic factors, such as BDNF/NT3, can regulate AIS position (Guo et al., 2017).

The morphology of the assembled AIS can also adapt in response to changes in activity: diminished activity results in AIS lengthening (Kuba et al., 2010), and elevated activity leads to a distal shift along the axon (Grubb and Burrone, 2010). This morphological plasticity has been observed in neuronal cultures (Grubb and Burrone, 2010; Chand et al., 2015), in organotypic brain slices (Wefelmeyer et al., 2015), in human pluripotent stem cell-derived neurons (Horschitz et al., 2015), and in vivo (Kuba et al., 2010). It is thought to alter intrinsic excitability in a homeostatic direction (Grubb and Burrone, 2010; Wefelmeyer et al.,
2016). However, the exact consequence of the AIS lengthening or distal shift on the intrinsic excitability is not trivial, as it depends on the overall morphology of the dendritic arbor (Brette, 2013; Gulledge and Bravo, 2016; Hamada et al., 2016). More subtle effects, such as a switch in ion channel composition between Kv7 and Kv1 (Kuba et al., 2015), antagonistic phospho-dependent regulation of Nav channels (Evans et al., 2015), or separation between the AIS scaffold and inhibitory synapses along the proximal axon (Muir and Kittler, 2014; Wefelmeyer et al., 2015), contribute to the modulation of excitability. A new type of plasticity involving a distal shift has also been observed recently in response to inhibition of Kv7 channel activity (Lezmy et al., 2017).

What are the molecular mechanisms of AIS morphological plasticity? Phosphorylation can strengthen or loosen multiple interactions within the AIS scaffold, providing a starting point for morphological changes. Protein kinase CK2 regulates the interaction between ankyrin $\mathrm{G}$ and $\mathrm{Nav}$ as well as Kv7 channels (Bréchet et al., 2008; Hien et al., 2014; Xu and Cooper, 2015), and it is implicated in Kv7-mediated plasticity (Lezmy et al., 2017). The kinase Cdk5 is implicated in regulating AIS length (Trunova et al., 2011; Chand et al., 2015), and the phosphatase calcineurin drives the distal shift in response to elevated activity (Evans et al., 2013), but in both cases the target and precise site of action are unknown. Other kinases, such as CaMKII (Hund et al., 2010) and GSK3 $\beta$ (Tapia et al., 2013), are anchored to the AIS scaffold, but their role in regulating the scaffold remains elusive. Degradation of AIS components could also play a role in morphological plasticity, as calpain can degrade AIS components after ischemic injury or excitotoxic events (Schafer et al., 2009; Del Puerto et al., 2015; Benned-Jensen et al., 2016).

Changes in the AIS position must ultimately be driven by cytoskeletal adjustments. Actomyosin contractility has been implicated in this process (Evans et al., 2017), and the distal shift caused by hyper-phosphorylated tau suggests microtubule involvement as well (Hatch et al., 2017). A structural understanding of AIS morphological plasticity awaits future studies. New insight may come from studies in genetically tractable organisms, such as Drosophila, where the proximal axon has recently been shown to possess trafficking-related features of the mammalian AIS (Trunova et al., 2011; Rolls and Jegla, 2015; Jegla et al., 2016).

Finally, plasticity and alteration of AIS components are implicated in a variety of nervous system pathologies, such as epilepsy (particularly forms caused by mutations in AIS-concentrated ion channels), neurodegeneration (Sun et al., 2014; Tsushima et al., 2015; Zempel et al., 2017), neuroinflammatory/demyelinating diseases (Hamada and Kole, 2015; Clark et al., 2016; Benusa et al., 2017), and bipolar disorders and schizophrenia (Luoni et al., 2016; Kloth et al., 2017; Lopez et al., 2017; Zhu et al., 2017). A complete overview of AIS involvement in pathological situations is beyond the scope of this Viewpoints article; in addition to the latest studies cited above, the interested reader is referred to several comprehensive reviews (Wimmer et al., 2010; Buffington and Rasband, 2011; Hsu et al., 2014).

\section{Future questions for AIS cell biologists}

In conclusion, the AIS is a complex assembly of membrane proteins, scaffold proteins, and cytoskeletal adaptors. It has key roles in neuronal physiology, as it drives excitability and maintains polarity. It is exquisitely regulated and can adapt its composition and morphology during development and adult life. I would like to finish by highlighting a couple of key cell biology questions about the AIS that are still unresolved. The first one is the exact mechanism(s) for trafficking of cargoes at the axon entrance. 
Advances have been made recently, but the puzzle still lacks a few important pieces: How is the sequence of traffic events coordinated? Are all microtubules within the axon hillock and the AIS equivalent or are there different populations for anterograde, retrograde, short and long distances transport? The second question is the structural mechanisms underlying AIS morphological plasticity. When the position of the AIS changes along the axon, does the AIS slide as a whole or does it disassemble and reassemble at its extremities? Is the position of the AIS driven by the submembrane actin scaffold via contractility mechanisms or by intracellular interactions between ankyrin $\mathrm{G}$ and microtubules? Future work will undoubtedly shed light on these questions and buttress the crucial role of the AIS in neuronal organization and function.

\section{References}

Akhmanova A, Hoogenraad CC (2015) Microtubule minus-end-targeting proteins. Curr Biol 25:R162-R171. CrossRef Medline

Akin EJ, Solé L, Dib-Hajj SD, Waxman SG, Tamkun MM (2015) Preferential targeting of Nav1.6 voltage-gated $\mathrm{Na}^{+}$channels to the axon initial segment during development. PLoS One 10:e0124397. CrossRef Medline

Al-Bassam S, Xu M, Wandless TJ, Arnold DB (2012) Differential trafficking of transport vesicles contributes to the localization of dendritic proteins. Cell Rep 2:89-100. CrossRef Medline

Albrecht D, Winterflood CM, Sadeghi M, Tschager T, Noé F, Ewers H (2016) Nanoscopic compartmentalization of membrane protein motion at the axon initial segment. J Cell Biol 215:37-46. CrossRef Medline

Angelides KJ, Elmer LW, Loftus D, Elson E (1988) Distribution and lateral mobility of voltage-dependent sodium channels in neurons. J Cell Biol 106:1911-1925. CrossRef Medline

Aumeier C, Schaedel L, Gaillard J, John K, Blanchoin L, Théry M (2016) Self-repair promotes microtubule rescue. Nat Cell Biol 18:1054-1064. CrossRef Medline

Baas PW, Lin S (2011) Hooks and comets: the story of microtubule polarity orientation in the neuron. Dev Neurobiol 71:403-418. CrossRef Medline

Baas PW, Ahmad FJ, Pienkowski TP, Brown A, Black MM (1993) Sites of microtubule stabilization for the axon. J Neurosci 13:2177-2185. Medline

Balasanyan V, Watanabe K, Dempsey WP, Lewis TL Jr, Trinh LA, Arnold DB (2017) Structure and function of an actin-based filter in the proximal axon. Cell Rep 21:2696-2705. CrossRef Medline

Barry J, Gu Y, Jukkola P, O’Neill B, Gu H, Mohler PJ, Rajamani KT, Gu C (2014) Ankyrin-G directly binds to kinesin-1 to transport voltage-gated $\mathrm{Na}^{+}$channels into axons. Dev Cell 28:117-131. CrossRef Medline

Bender KJ, Ford CP, Trussell LO (2010) Dopaminergic modulation of axon initial segment calcium channels regulates action potential initiation. Neuron 68:500-511. CrossRef Medline

Benned-Jensen T, Christensen RK, Denti F, Perrier JF, Rasmussen HB, Olesen SP (2016) Live imaging of Kv7.2/7.3 cell surface dynamics at the axon initial segment: high steady-state stability and calpain-dependent excitotoxic downregulation revealed. J Neurosci 36:2261-2266. CrossRef Medline

Bennett V, Lorenzo DN (2013) Spectrin- and ankyrin-based membrane domains and the evolution of vertebrates. Curr Top Membr 72:1-37. CrossRef Medline

Bennett V, Davis J, Fowler WE (1982) Brain spectrin, a membraneassociated protein related in structure and function to erythrocyte spectrin. Nature 299:126-131. CrossRef Medline

Bentley M, Banker G (2016) The cellular mechanisms that maintain neuronal polarity. Nat Rev Neurosci 17:611-622. CrossRef Medline

Benusa SD, George NM, Sword BA, DeVries GH, Dupree JL (2017) Acute neuroinflammation induces AIS structural plasticity in a NOX2dependent manner. J Neuroinflammation 14:116. CrossRef Medline

Berghs S, Aggujaro D, Dirkx R Jr, Maksimova E, Stabach P, Hermel JM, Zhang JP, Philbrick W, Slepnev V, Ort T, Solimena M (2000) betaIV spectrin, a new spectrin localized at axon initial segments and nodes of Ranvier in the central and peripheral nervous system. J Cell Biol 151:9851002. CrossRef Medline

Boiko T, Vakulenko M, Ewers H, Yap CC, Norden C, Winckler B (2007) Ankyrin-dependent and -independent mechanisms orchestrate axonal compartmentalization of L1 family members neurofascin and L1/
Neuron-glia cell adhesion molecule. J Neurosci 27:590-603. CrossRef Medline

Brachet A, Leterrier C, Irondelle M, Fache MP, Racine V, Sibarita JB, Choquet D, Dargent B (2010) Ankyrin G restricts ion channel diffusion at the axonal initial segment before the establishment of the diffusion barrier. J Cell Biol 191:383-395. CrossRef Medline

Bréchet A, Fache MP, Brachet A, Ferracci G, Baude A, Irondelle M, Pereira S, Leterrier C, Dargent B (2008) Protein kinase CK2 contributes to the organization of sodium channels in axonal membranes by regulating their interactions with ankyrin G. J Cell Biol 183:1101-1114. CrossRef Medline

Breslow DK, Koslover EF, Seydel F, Spakowitz AJ, Nachury MV (2013) An in vitro assay for entry into cilia reveals unique properties of the soluble diffusion barrier. J Cell Biol 203:129-147. CrossRef Medline

Brette R (2013) Sharpness of spike initiation in neurons explained by compartmentalization. PLoS Comput Biol 9:e1003338. CrossRef Medline

Brouhard GJ (2015) Dynamic instability 30 years later: complexities in microtubule growth and catastrophe. Mol Biol Cell 26:1207-1210. CrossRef Medline

Buffington SA, Rasband MN (2011) The axon initial segment in nervous system disease and injury. Eur J Neurosci 34:1609-1619. CrossRef Medline

Burack MA, Silverman MA, Banker G (2000) The role of selective transport in neuronal protein sorting. Neuron 26:465-472. CrossRef Medline

Chand AN, Galliano E, Chesters RA, Grubb MS (2015) A distinct subtype of dopaminergic interneuron displays inverted structural plasticity at the axon initial segment. J Neurosci 35:1573-1590. CrossRef Medline

Clark BD, Goldberg EM, Rudy B (2009) Electrogenic tuning of the axon initial segment. Neuroscientist 15:651-668. CrossRef Medline

Clark KC, Josephson A, Benusa SD, Hartley RK, Baer M, Thummala S, Joslyn M, Sword BA, Elford H, Oh U, Dilsizoglu-Senol A, Lubetzki C, Davenne M, DeVries GH, Dupree JL (2016) Compromised axon initial segment integrity in EAE is preceded by microglial reactivity and contact. Glia 64:1190-1209. CrossRef Medline

Cooper EC (2011) Made for "anchorin": Kv7.2/7.3 (KCNQ2/KCNQ3) channels and the modulation of neuronal excitability in vertebrate axons. Semin Cell Dev Biol 22:185-192. CrossRef Medline

Cotel F, Exley R, Cragg SJ, Perrier JF (2013) Serotonin spillover onto the axon initial segment of motoneurons induces central fatigue by inhibiting action potential initiation. Proc Natl Acad Sci U S A 110:4774-4779. CrossRef Medline

Cruz DA, Lovallo EM, Stockton S, Rasband M, Lewis DA (2009) Postnatal development of synaptic structure proteins in pyramidal neuron axon initial segments in monkey prefrontal cortex. J Comp Neurol 514:353367. CrossRef Medline

Davis JQ, Lambert S, Bennett V (1996) Molecular composition of the node of Ranvier: identification of ankyrin-binding cell adhesion molecules neurofascin $\left(\right.$ mucin $^{+}$/third FNIII domain ${ }^{-}$) and NrCAM at nodal axon segments. J Cell Biol 135:1355-1367. CrossRef Medline

Del Puerto A, Fronzaroli-Molinieres L, Perez-Alvarez MJ, Giraud P, Carlier E, Wandosell F, Debanne D, Garrido JJ (2015) ATP-P2X7 receptor modulates axon initial segment composition and function in physiological conditions and brain injury. Cereb Cortex 25:2282-2294. CrossRef Medline

D’Este E, Kamin D, Göttfert F, El-Hady A, Hell SW (2015) STED nanoscopy reveals the ubiquity of subcortical cytoskeleton periodicity in living neurons. Cell Rep 10:1246-1251. CrossRef Medline

D'Este E, Kamin D, Balzarotti F, Hell SW (2017) Ultrastructural anatomy of nodes of Ranvier in the peripheral nervous system as revealed by STED microscopy. Proc Natl Acad Sci U S A 114:E191-E199. CrossRef Medline

Dimitrov A, Quesnoit M, Moutel S, Cantaloube I, Poüs C, Perez F (2008) Detection of GTP-tubulin conformation in vivo reveals a role for GTP remnants in microtubule rescues. Science 322:1353-1356. CrossRef Medline

Dotti CG, Simons K (1990) Polarized sorting of viral glycoproteins to the axon and dendrites of hippocampal neurons in culture. Cell 62:63-72. CrossRef Medline

Dover K, Marra C, Solinas S, Popovic M, Subramaniyam S, Zecevic D, D’Angelo E, Goldfarb M (2016) FHF-independent conduction of action potentials along the leak-resistant cerebellar granule cell axon. Nat Commun 7:12895. CrossRef Medline

Duménieu M, Oulé M, Kreutz MR, Lopez-Rojas J (2017) The segregated expression of voltage-gated potassium and sodium channels in neuronal 
membranes: functional implications and regulatory mechanisms. Front Cell Neurosci 11:115. CrossRef Medline

Dumont EL, Do C, Hess H (2015) Molecular wear of microtubules propelled by surface-adhered kinesins. Nat Nanotechnol 10:166-169. CrossRef Medline

Dzhashiashvili Y, Zhang Y, Galinska J, Lam I, Grumet M, Salzer JL (2007) Nodes of Ranvier and axon initial segments are ankyrin G-dependent domains that assemble by distinct mechanisms. J Cell Biol 177:857-870. CrossRef Medline

Evans MD, Sammons RP, Lebron S, Dumitrescu AS, Watkins TB, Uebele VN, Renger JJ, Grubb MS (2013) Calcineurin signaling mediates activitydependent relocation of the axon initial segment. J Neurosci 33:69506963. CrossRef Medline

Evans MD, Dumitrescu AS, Kruijssen DL, Taylor SE, Grubb MS (2015) Rapid modulation of axon initial segment length influences repetitive spike firing. Cell Rep 13:1233-1245. CrossRef Medline

Evans MD, Tufo C, Dumitrescu AS, Grubb MS (2017) Myosin II activity is required for structural plasticity at the axon initial segment. Eur J Neurosci 46:1751-1757. CrossRef Medline

Fache MP, Moussif A, Fernandes F, Giraud P, Garrido JJ, Dargent B (2004) Endocytotic elimination and domain-selective tethering constitute a potential mechanism of protein segregation at the axonal initial segment. J Cell Biol 166:571-578. CrossRef Medline

Farías GG, Guardia CM, Britt DJ, Guo X, Bonifacino JS (2015) Sorting of dendritic and axonal vesicles at the pre-axonal exclusion zone. Cell Rep 13:1221-1232. CrossRef Medline

Franssen EH, Zhao RR, Koseki H, Kanamarlapudi V, Hoogenraad CC, Eva R, Fawcett JW (2015) Exclusion of integrins from CNS axons is regulated by Arf6 activation and the AIS. J Neurosci 35:8359-8375. CrossRef Medline

Fréal A, Fassier C, Le Bras B, Bullier E, De Gois S, Hazan J, Hoogenraad CC, Couraud F (2016) Cooperative interactions between $480 \mathrm{kDa}$ ankyrin-G and EB proteins assemble the axon initial segment. J Neurosci 36:4421-4433. CrossRef Medline

Galiano MR, Jha S, Ho TS, Zhang C, Ogawa Y, Chang KJ, Stankewich MC, Mohler PJ, Rasband MN (2012) A distal axonal cytoskeleton forms an intra-axonal boundary that controls axon initial segment assembly. Cell 149:1125-1139. CrossRef Medline

Garrido JJ, Giraud P, Carlier E, Fernandes F, Moussif A, Fache MP, Debanne D, Dargent B (2003) A targeting motif involved in sodium channel clustering at the axonal initial segment. Science 300:2091-2094. CrossRef Medline

Gasser A, Ho TS, Cheng X, Chang KJ, Waxman SG, Rasband MN, Dib-Hajj SD (2012) An ankyrinG-binding motif is necessary and sufficient for targeting Nav1.6 sodium channels to axon initial segments and nodes of Ranvier. J Neurosci 32:7232-7243. CrossRef Medline

Grubb MS, Burrone J (2010) Activity-dependent relocation of the axon initial segment fine-tunes neuronal excitability. Nature 465:1070-1074. CrossRef Medline

Grubb MS, Shu Y, Kuba H, Rasband MN, Wimmer VC, Bender KJ (2011) Short- and long-term plasticity at the axon initial segment. J Neurosci 31:16049-16055. CrossRef Medline

Gulledge AT, Bravo JJ (2016) Neuron morphology influences axon initial segment plasticity. eNeuro 3:ENEURO.0085-15-2016. CrossRef Medline

Gumy LF, Katrukha EA, Grigoriev I, Jaarsma D, Kapitein LC, Akhmanova A, Hoogenraad CC (2017) MAP2 defines a pre-axonal filtering zone to regulate KIF1- versus KIF5-dependent cargo transport in sensory neurons. Neuron 94:347-362.e7. CrossRef Medline

Guo X, Farías GG, Mattera R, Bonifacino JS (2016) Rab5 and its effector FHF contribute to neuronal polarity through dynein-dependent retrieval of somatodendritic proteins from the axon. Proc Natl Acad Sci U S A 113:E5318-E5327. CrossRef Medline

Guo Y, Su ZJ, Chen YK, Chai Z (2017) Brain-derived neurotrophic factor/ neurotrophin 3 regulate axon initial segment location and affect neuronal excitability in cultured hippocampal neurons. J Neurochem 142:260271. CrossRef Medline

Gutzmann A, Ergül N, Grossmann R, Schultz C, Wahle P, Engelhardt M (2014) A period of structural plasticity at the axon initial segment in developing visual cortex. Front Neuroanat 8:11. CrossRef Medline

Hamada MS, Kole MH (2015) Myelin loss and axonal ion channel adaptations associated with gray matter neuronal hyperexcitability. J Neurosci 35:7272-7286. CrossRef Medline
Hamada MS, Goethals S, de Vries SI, Brette R, Kole MH (2016) Covariation of axon initial segment location and dendritic tree normalizes the somatic action potential. Proc Natl Acad Sci U S A 113:14841-14846. CrossRef Medline

Hammond JW, Huang CF, Kaech S, Jacobson C, Banker G, Verhey KJ (2010) Posttranslational modifications of tubulin and the polarized transport of kinesin-1 in neurons. Mol Biol Cell 21:572-583. CrossRef Medline

Hatch RJ, Wei Y, Xia D, Götz J (2017) Hyperphosphorylated tau causes reduced hippocampal CA1 excitability by relocating the axon initial segment. Acta Neuropathol 133:717-730. CrossRef Medline

He M, Jenkins P, Bennett V (2012) Cysteine 70 of ankyrin-G is S-palmitoylated and is required for function of ankyrin-G in membrane domain assembly. J Biol Chem 287:43995-44005. CrossRef Medline

Hedstrom KL, Xu X, Ogawa Y, Frischknecht R, Seidenbecher CI, Shrager P, Rasband MN (2007) Neurofascin assembles a specialized extracellular matrix at the axon initial segment. J Cell Biol 178:875-886. CrossRef Medline

Hedstrom KL, Ogawa Y, Rasband MN (2008) AnkyrinG is required for maintenance of the axon initial segment and neuronal polarity. J Cell Biol 183:635-640. CrossRef Medline

Hien YE, Montersino A, Castets F, Leterrier C, Filhol O, Vacher H, Dargent B (2014) CK2 accumulation at the axon initial segment depends on sodium channel Nav1. FEBS Lett 588:3403-3408. CrossRef Medline

Höfflin F, Jack A, Riedel C, Mack-Bucher J, Roos J, Corcelli C, Schultz C, Wahle P, Engelhardt M (2017) Heterogeneity of the axon initial segment in interneurons and pyramidal cells of rodent visual cortex. Front Cell Neurosci 11:255. CrossRef Medline

Horschitz S, Matthäus F, Groß A, Rosner J, Galach M, Greffrath W, Treede RD, Utikal J, Schloss P, Meyer-Lindenberg A (2015) Impact of preconditioning with retinoic acid during early development on morphological and functional characteristics of human induced pluripotent stem cellderived neurons. Stem Cell Res 15:30-41. CrossRef Medline

Hsu WC, Nilsson CL, Laezza F (2014) Role of the axonal initial segment in psychiatric disorders: function, dysfunction, and intervention. Front Psychiatry 5:109. CrossRef Medline

Huang CF, Banker G (2012) The translocation selectivity of the kinesins that mediate neuronal organelle transport. Traffic 13:549-564. CrossRef Medline

Huang CY, Zhang C, Ho TS, Oses-Prieto J, Burlingame AL, Lalonde J, Noebels JL, Leterrier C, Rasband MN (2017a) $\alpha$ II spectrin forms a periodic cytoskeleton at the axon initial segment and is required for nervous system function. J Neurosci 37:11311-11322. CrossRef Medline

Huang CY, Zhang C, Zollinger DR, Leterrier C, Rasband MN (2017b) An $\alpha$ II spectrin-based cytoskeleton protects large-diameter myelinated axons from degeneration. J Neurosci 37:11323-11334. CrossRef Medline

Huang YM, Rasband MN (2016) Organization of the axon initial segment: actin like a fence. J Cell Biol 215:9-11. CrossRef Medline

Hull JM, Isom LL (2017) Voltage-gated sodium channel $\beta$ subunits: the power outside the pore in brain development and disease. Neuropharmacology. Advance online publication. Retrieved Sep. 18, 2017. doi: 10.1016/ j.neuropharm.2017.09.018. CrossRef Medline

Hund TJ, Koval OM, Li J, Wright PJ, Qian L, Snyder JS, Gudmundsson H, Kline CF, Davidson NP, Cardona N, Rasband MN, Anderson ME, Mohler PJ (2010) A $\beta(I V)$-spectrin/CaMKII signaling complex is essential for membrane excitability in mice. J Clin Invest 120:3508-3519. CrossRef Medline

Inda MC, DeFelipe J, Muñoz A (2006) Voltage-gated ion channels in the axon initial segment of human cortical pyramidal cells and their relationship with chandelier cells. Proc Natl Acad Sci U S A 103:2920-2925. CrossRef Medline

Jamann N, Jordan M, Engelhardt M (2018) Activity-dependent axonal plasticity in sensory systems. Neuroscience 368:268-282. CrossRef Medline

Janke C (2014) The tubulin code: molecular components, readout mechanisms, and functions. J Cell Biol 206:461-472. CrossRef Medline

Janssen AF, Tas RP, van Bergeijk P, Oost R, Hoogenraad CC, Kapitein LC (2017) Myosin-V induces cargo immobilization and clustering at the axon initial segment. Front Cell Neurosci 11:89. CrossRef Medline

Jegla T, Nguyen MM, Feng C, Goetschius DJ, Luna E, van Rossum DB, Kamel B, Pisupati A, Milner ES, Rolls MM (2016) Bilaterian giant ankyrins have a common evolutionary origin and play a conserved role in patterning the axon initial segment. PLoS Genet 12:e1006457. CrossRef Medline Jenkins PM, Kim N, Jones SL, Tseng WC, Svitkina TM, Yin HH, Bennett V 
(2015) Giant ankyrin-G: a critical innovation in vertebrate evolution of fast and integrated neuronal signaling. Proc Natl Acad Sci U S A 112:957964. CrossRef Medline

Jenkins SM, Bennett V (2001) Ankyrin-G coordinates assembly of the spectrin-based membrane skeleton, voltage-gated sodium channels, and L1 CAMs at purkinje neuron initial segments. J Cell Biol 155:739-746. CrossRef Medline

Jensen CS, Watanabe S, Stas JI, Klaphaak J, Yamane A, Schmitt N, Olesen SP, Trimmer JS, Rasmussen HB, Misonou H (2017) Trafficking of Kv2.1 channels to the axon initial segment by a novel nonconventional secretory pathway. J Neurosci 37:11523-11536. CrossRef Medline

Jones EG, Powell TP (1969) Synapses on the axon hillocks and initial segments of pyramidal cell axons in the cerebral cortex. J Cell Sci 5:495-507. Medline

Jones SL, Svitkina TM (2016) Axon initial segment cytoskeleton: architecture, development, and role in neuron polarity. Neural Plast 2016: 6808293. CrossRef Medline

Jones SL, Korobova F, Svitkina T (2014) Axon initial segment cytoskeleton comprises a multiprotein submembranous coat containing sparse actin filaments. J Cell Biol 205:67-81. CrossRef Medline

Kapitein LC, Hoogenraad CC (2015) Building the neuronal microtubule cytoskeleton. Neuron 87:492-506. CrossRef Medline

King AN, Manning CF, Trimmer JS (2014) A unique ion channel clustering domain on the axon initial segment of mammalian neurons. J Comp Neurol 522:2594-2608. CrossRef Medline

Klinman E, Tokito M, Holzbaur EL (2017) CDK5-dependent activation of dynein in the axon initial segment regulates polarized cargo transport in neurons. Traffic 18:808-824. CrossRef Medline

Kloth K, Denecke J, Hempel M, Johannsen J, Strom TM, Kubisch C, Lessel D (2017) First de novo ANK3 nonsense mutation in a boy with intellectual disability, speech impairment and autistic features. Eur J Med Genet 60: 494-498. CrossRef Medline

Kneynsberg A, Kanaan NM (2017) Aging does not affect axon initial segment structure and somatic localization of tau protein in hippocampal neurons of Fischer344 rats. 4:ENEURO.0043-17.2017.

Ko KW, Rasband MN, Meseguer V, Kramer RH, Golding NL (2016) Serotonin modulates spike probability in the axon initial segment through HCN channels. Nat Neurosci 19:826-834. CrossRef Medline

Kobayashi T, Storrie B, Simons K, Dotti CG (1992) A functional barrier to movement of lipids in polarized neurons. Nature 359:647-650. CrossRef Medline

Kole MH, Stuart GJ (2012) Signal processing in the axon initial segment. Neuron 73:235-247. CrossRef Medline

Kole MH, Letzkus JJ, Stuart GJ (2007) Axon initial segment Kv1 channels control axonal action potential waveform and synaptic efficacy. Neuron 55:633-647. CrossRef Medline

Kole MH, Ilschner SU, Kampa BM, Williams SR, Ruben PC, Stuart GJ (2008) Action potential generation requires a high sodium channel density in the axon initial segment. Nat Neurosci 11:178-186. CrossRef Medline

Komada M, Soriano P (2002) [Beta]IV-spectrin regulates sodium channel clustering through ankyrin- $\mathrm{G}$ at axon initial segments and nodes of Ranvier. J Cell Biol 156:337-348. CrossRef Medline

Konishi Y, Setou M (2009) Tubulin tyrosination navigates the kinesin-1 motor domain to axons. Nat Neurosci 12:559-567. CrossRef Medline

Kordeli E, Lambert S, Bennett V (1995) AnkyrinG: a new ankyrin gene with neural-specific isoforms localized at the axonal initial segment and node of Ranvier. J Biol Chem 270:2352-2359. CrossRef Medline

Kosaka T (1980) The axon initial segment as a synaptic site: ultrastructure and synaptology of the initial segment of the pyramidal cell in the rat hippocampus (CA3 region). J Neurocytol 9:861-882. CrossRef Medline

Krieg M, Dunn AR, Goodman MB (2014) Mechanical control of the sense of touch by $\beta$-spectrin. Nat Cell Biol 16:224-233. CrossRef Medline

Krieg M, Stühmer J, Cueva JG, Fetter R, Spliker KA, Cremers D, Shen K, Dunn AR, Goodman MB (2017) Genetic defects in $\beta$-spectrin and tau sensitize $C$. elegans axons to movement-induced damage via torquetension coupling. Elife 6:1187. CrossRef Medline

Kuba H, Oichi Y, Ohmori H (2010) Presynaptic activity regulates $\mathrm{Na}(+)$ channel distribution at the axon initial segment. Nature 465:1075-1078. CrossRef Medline

Kuba H, Adachi R, Ohmori H (2014) Activity-dependent and activityindependent development of the axon initial segment. J Neurosci 34: 3443-3453. CrossRef Medline
Kuba H, Yamada R, Ishiguro G, Adachi R (2015) Redistribution of Kvl and Kv7 enhances neuronal excitability during structural axon initial segment plasticity. Nat Commun 6:8815. CrossRef Medline

Kuijpers M, van de Willige D, Fréal A, Chazeau A, Franker MA, Hofenk J Rodrigues RJ, Kapitein LC, Akhmanova A, Jaarsma D, Hoogenraad CC (2016) Dynein regulator NDEL1 controls polarized cargo transport at the axon initial segment. Neuron 89:461-471. CrossRef Medline

Le Bras B, Fréal A, Czarnecki A, Legendre P, Bullier E, Komada M, Brophy PJ, Davenne $M$, Couraud F (2014) In vivo assembly of the axon initial segment in motor neurons. Brain Struct Funct 219:1433-1450. CrossRef Medline

Lemaillet G, Walker B, Lambert S (2003) Identification of a conserved ankyrin-binding motif in the family of sodium channel alpha subunits. J Biol Chem 278:27333-27339. CrossRef Medline

Leterrier C (2016) The axon initial segment, 50 years later: a nexus for neuronal organization and function. Curr Top Membr 77:185-233. CrossRef Medline

Leterrier C, Dargent B (2014) No Pasaran! Role of the axon initial segment in the regulation of protein transport and the maintenance of axonal identity. Semin Cell Dev Biol 27C:44-51. CrossRef Medline

Leterrier C, Brachet A, Fache MP, Dargent B (2010) Voltage-gated sodium channel organization in neurons: protein interactions and trafficking pathways. Neurosci Lett 486:92-100. CrossRef Medline

Leterrier C, Vacher H, Fache MP, Angles d'Ortoli SA, Castets F, AutilloTouati A, Dargent B (2011) End-binding proteins EB3 and EB1 link microtubules to ankyrin $\mathrm{G}$ in the axon initial segment. Proc Natl Acad Sci U S A 108:8826-8831. CrossRef Medline

Leterrier C, Potier J, Caillol G, Debarnot C, Rueda Boroni F, Dargent B (2015) Nanoscale architecture of the axon initial segment reveals an organized and robust scaffold. Cell Rep 13:2781-2793. CrossRef Medline

Leterrier C, Clerc N, Rueda-Boroni F, Montersino A, Dargent B, Castets F (2017a) Ankyrin G membrane partners drive the establishment and maintenance of the axon initial segment. Front Cell Neurosci 11:e136. CrossRef Medline

Leterrier C, Dubey P, Roy S (2017b) The nano-architecture of the axonal cytoskeleton. Nat Rev Neurosci 18:713-726. CrossRef Medline

Lewis TL Jr, Mao T, Svoboda K, Arnold DB (2009) Myosin-dependent targeting of transmembrane proteins to neuronal dendrites. Nat Neurosci 12:568-576. CrossRef Medline

Lezmy J, Lipinsky M, Khrapunsky Y, Patrich E, Shalom L, Peretz A, Fleidervish IA, Attali B (2017) M-current inhibition rapidly induces a unique CK2-dependent plasticity of the axon initial segment. Proc Natl Acad Sci U S A 23:201708700. CrossRef Medline

Li TP, Blanpied TA (2016) Control of transmembrane protein diffusion within the postsynaptic density assessed by simultaneous single-molecule tracking and localization microscopy. Front Synaptic Neurosci 8:19. CrossRef Medline

Li X, Kumar Y, Zempel H, Mandelkow EM, Biernat J, Mandelkow E (2011) Novel diffusion barrier for axonal retention of tau in neurons and its failure in neurodegeneration. EMBO J 30:4825-4837. CrossRef Medline

Lin YC, Niewiadomski P, Lin B, Nakamura H, Phua SC, Jiao J, Levchenko A, Inoue T, Rohatgi R, Inoue T (2013) Chemically inducible diffusion trap at cilia reveals molecular sieve-like barrier. Nat Chem Biol 9:437-443. CrossRef Medline

Lipka J, Kapitein LC, Jaworski J, Hoogenraad CC (2016) Microtubulebinding protein doublecortin-like kinase 1 (DCLK1) guides kinesin-3mediated cargo transport to dendrites. EMBO J 35:302-318. CrossRef Medline

Liu H, Dong P, Ioannou MS, Li L, Shea J, Pasolli HA, Grimm JB, Rivlin PK, Lavis LD, Koyama M, Liu Z (2018) Visualizing long-term singlemolecule dynamics in vivo by stochastic protein labeling. Proc Natl Acad Sci U S A 115:343-348. CrossRef Medline

Lopez AY, Wang X, Xu M, Maheshwari A, Curry D, Lam S, Adesina AM, Noebels JL, Sun QQ, Cooper EC (2017) Ankyrin-G isoform imbalance and interneuronopathy link epilepsy and bipolar disorder. Mol Psychiatry 22:1464-1472. CrossRef Medline

Lorincz A, Nusser Z (2008) Cell-type-dependent molecular composition of the axon initial segment. J Neurosci 28:14329-14340. CrossRef Medline

Lorincz A, Nusser Z (2010) Molecular identity of dendritic voltage-gated sodium channels. Science 328:906-909. CrossRef Medline

Luoni A, Massart R, Nieratschker V, Nemoda Z, Blasi G, Gilles M, Witt SH, Suderman MJ, Suomi SJ, Porcelli A, Rizzo G, Fazio L, Torretta S, 
Rampino A, Berry A, Gass P, Cirulli F, Rietschel M, Bertolino A, Deuschle M, et al. (2016) Ankyrin-3 as a molecular marker of early-life stress and vulnerability to psychiatric disorders. Transl Psychiatry 6:e943. CrossRef Medline

Martinello K, Huang Z, Lujan R, Tran B, Watanabe M, Cooper EC, Brown DA, Shah MM (2015) Cholinergic afferent stimulation induces axonal function plasticity in adult hippocampal granule cells. Neuron 85:346363. CrossRef Medline

Matsumoto E, Rosenbluth J (1985) Plasma membrane structure at the axon hillock, initial segment and cell body of frog dorsal root ganglion cells. J Neurocytol 14:731-747. CrossRef Medline

Maurer SP, Fourniol FJ, Bohner G, Moores CA, Surrey T (2012) EBs recognize a nucleotide-dependent structural cap at growing microtubule ends. Cell 149:371-382. CrossRef Medline

Muir J, Kittler JT (2014) Plasticity of GABAA receptor diffusion dynamics at the axon initial segment. Front Cell Neurosci 8:151. CrossRef Medline

Nakada C, Ritchie K, Oba Y, Nakamura M, Hotta Y, Iino R, Kasai RS, Yamaguchi K, Fujiwara T, Kusumi A (2003) Accumulation of anchored proteins forms membrane diffusion barriers during neuronal polarization. Nat Cell Biol 5:626-632. CrossRef Medline

Nakata T, Hirokawa N (2003) Microtubules provide directional cues for polarized axonal transport through interaction with kinesin motor head. J Cell Biol 162:1045-1055. CrossRef Medline

Nakata T, Niwa S, Okada Y, Perez F, Hirokawa N (2011) Preferential binding of a kinesin-1 motor to GTP-tubulin-rich microtubules underlies polarized vesicle transport. J Cell Biol 194:245-255. CrossRef Medline

Nelson AD, Jenkins PM (2017) Axonal membranes and their domains: assembly and function of the axon initial segment and node of Ranvier. Front Cell Neurosci 11:136. CrossRef Medline

Nirschl JJ, Ghiretti AE, Holzbaur EL (2017) The impact of cytoskeletal organization on the local regulation of neuronal transport. Nat Rev Neurosci 18:585-597. CrossRef Medline

Normand EA, Rasband MN (2015) Subcellular patterning: axonal domains with specialized structure and function. Dev Cell 32:459-468. CrossRef Medline

Nozari M, Suzuki T, Rosa MG, Yamakawa K, Atapour N (2017) The impact of early environmental interventions on structural plasticity of the axon initial segment in neocortex. Dev Psychobiol 59:39-47. CrossRef Medline

Ogawa Y, Horresh I, Trimmer JS, Bredt DS, Peles E, Rasband MN (2008) Postsynaptic density-93 clusters Kv1 channels at axon initial segments independently of Caspr2. J Neurosci 28:5731-5739. CrossRef Medline

Pablo JL, Wang C, Presby MM, Pitt GS (2016) Polarized localization of voltage-gated $\mathrm{Na}^{+}$channels is regulated by concerted FGF13 and FGF14 action. Proc Natl Acad Sci U S A 113:E2665-E2674. CrossRef Medline

Palay SL, Sotelo C, Peters A, Orkand PM (1968) The axon hillock and the initial segment. J Cell Biol 38:193-201. CrossRef Medline

Pan Z, Kao T, Horvath Z, Lemos J, Sul JY, Cranstoun S, Bennett V, Scherer SS, Cooper EC (2006) A common ankyrin-G-based mechanism retains KCNQ and NaV channels at electrically active domains of the axon. J Neurosci 26:2599-2613. CrossRef Medline

Peters A, Proskauer CC, Kaiserman-Abramof IR (1968) The small pyramidal neuron of the rat cerebral cortex. the axon hillock and initial segment. J Cell Biol 39:604-619. CrossRef Medline

Petersen AV, Cotel F, Perrier JF (2016) Plasticity of the axon initial segment: fast and slow processes with multiple functional roles. Neuroscientist. Advance online publication. Retrieved May 3, 2016. doi: 10.1177/ 1073858416648311. CrossRef Medline

Petersen JD, Kaech S, Banker G (2014) Selective microtubule-based transport of dendritic membrane proteins arises in concert with axon specification. J Neurosci 34:4135-4147. CrossRef Medline

Rasband MN (2010a) The axon initial segment and the maintenance of neuronal polarity. Nat Rev Neurosci 11:552-562. CrossRef Medline

Rasband MN (2010b) Clustered $\mathrm{K}^{+}$channel complexes in axons. Neurosci Lett 486:101-106. CrossRef Medline

Renner ML, Cognet L, Lounis B, Triller A, Choquet D (2009) The excitatory postsynaptic density is a size exclusion diffusion environment. Neuropharmacology 56:30-36. CrossRef Medline

Rolls MM, Jegla TJ (2015) Neuronal polarity: an evolutionary perspective. J Exp Biol 218:572-580. CrossRef Medline

Sarmiere PD, Weigle CM, Tamkun MM (2008) The Kv2.1 K ${ }^{+}$channel tar- gets to the axon initial segment of hippocampal and cortical neurons in culture and in situ. BMC Neurosci 9:112. CrossRef Medline

Satake T, Yamashita K, Hayashi K, Miyatake S, Tamura-Nakano M, Doi H, Furuta Y, Shioi G, Miura E, Takeo YH, Yoshida K, Yahikozawa H, Matsumoto N, Yuzaki M, Suzuki A (2017) MTCL1 plays an essential role in maintaining purkinje neuron axon initial segment. EMBO J 36:12271242. CrossRef Medline

Schaedel L, John K, Gaillard J, Nachury MV, Blanchoin L, Théry M (2015) Microtubules self-repair in response to mechanical stress. Nat Mater 14: 1156-1163. CrossRef Medline

Schafer DP, Jha S, Liu F, Akella T, McCullough LD, Rasband MN (2009) Disruption of the axon initial segment cytoskeleton is a new mechanism for neuronal injury. J Neurosci 29:13242-13254. CrossRef Medline

Schlüter A, Del Turco D, Deller T, Gutzmann A, Schultz C, Engelhardt M (2017) Structural plasticity of synaptopodin in the axon initial segment during visual cortex development. Cereb Cortex 27:4662-4675. CrossRef Medline

Shah MM, Migliore M, Valencia I, Cooper EC, Brown DA (2008) Functional significance of axonal Kv7 channels in hippocampal pyramidal neurons. Proc Natl Acad Sci U S A 105:7869-7874. CrossRef Medline

Sobotzik JM, Sie JM, Politi C, Del Turco D, Bennett V, Deller T, Schultz C (2009) Ankyring is required to maintain axo-dendritic polarity in vivo. Proc Natl Acad Sci U S A 106:17564-17569. CrossRef Medline

Song AH, Wang D, Chen G, Li Y, Luo J, Duan S, Poo MM (2009) A selective filter for cytoplasmic transport at the axon initial segment. Cell 136:1148 1160. CrossRef Medline

Srinivasan Y, Elmer L, Davis J, Bennett V, Angelides K (1988) Ankyrin and spectrin associate with voltage-dependent sodium channels in brain. $\mathrm{Na}$ ture 333:177-180. CrossRef Medline

Sun X, Wu Y, Gu M, Liu Z, Ma Y, Li J, Zhang Y (2014) Selective filtering defect at the axon initial segment in Alzheimer's disease mouse models. Proc Natl Acad Sci U S A 111:14271-14276. CrossRef Medline

Tapia M, Wandosell F, Garrido JJ (2010) Impaired function of HDAC6 slows down axonal growth and interferes with axon initial segment development. PLoS One 5:e12908. CrossRef Medline

Tapia M, Del Puerto A, Puime A, Sánchez-Ponce D, Fronzaroli-Molinieres L, Pallas-Bazarra N, Carlier E, Giraud P, Debanne D, Wandosell F, Garrido JJ (2013) GSK3 and $\beta$-catenin determines functional expression of sodium channels at the axon initial segment. Cell Mol Life Sci 70:105-120. CrossRef Medline

Thome C, Kelly T, Yanez A, Schultz C, Engelhardt M, Cambridge SB, Both M, Draguhn A, Beck H, Egorov AV (2014) Axon-carrying dendrites convey privileged synaptic input in hippocampal neurons. Neuron 83:14181430. CrossRef Medline

Trunova S, Baek B, Giniger E (2011) Cdk5 regulates the size of an axon initial segment-like compartment in mushroom body neurons of the Drosophila central brain. J Neurosci 31:10451-10462. CrossRef Medline

Tsushima H, Emanuele M, Polenghi A, Esposito A, Vassalli M, Barberis A, Difato F, Chieregatti E (2015) HDAC6 and RhoA are novel players in abeta-driven disruption of neuronal polarity. Nat Commun 6:7781. CrossRef Medline

Vacher H, Yang JW, Cerda O, Autillo-Touati A, Dargent B, Trimmer JS (2011) Cdk-mediated phosphorylation of the $\operatorname{Kv} \beta 2$ auxiliary subunit regulates Kv1 channel axonal targeting. J Cell Biol 192:813-824. CrossRef Medline

van Beuningen SF, Will L, Harterink M, Chazeau A, van Battum EY, Frias CP, Franker MA, Katrukha EA, Stucchi R, Vocking K, Antunes AT, Slenders L, Doulkeridou S, Sillevis Smitt P, Altelaar AF, Post JA, Akhmanova A, Pasterkamp RJ, Kapitein LC, de Graaff E, et al. (2015) TRIM46 controls neuronal polarity and axon specification by driving the formation of parallel microtubule arrays. Neuron 88:1208-1226. CrossRef Medline

van de Willige D, Hoogenraad CC, Akhmanova A (2016) Microtubule plusend tracking proteins in neuronal development. Cell Mol Life Sci 73: 2053-2077. CrossRef Medline

Van Wart A, Trimmer JS, Matthews G (2007) Polarized distribution of ion channels within microdomains of the axon initial segment. J Comp Neurol 500:339-352. CrossRef Medline

Wang C, Wei Z, Chen K, Ye F, Yu C, Bennett V, Zhang M (2014) Structural basis of diverse membrane target recognitions by ankyrins. Elife 3 .

Watanabe K, Al-Bassam S, Miyazaki Y, Wandless TJ, Webster P, Arnold DB (2012) Networks of polarized actin filaments in the axon initial segment 
provide a mechanism for sorting axonal and dendritic proteins. Cell Rep 2:1546-1553. CrossRef Medline

Wefelmeyer W, Cattaert D, Burrone J (2015) Activity-dependent mismatch between axo-axonic synapses and the axon initial segment controls neuronal output. Proc Natl Acad Sci U S A 112:9757-9762. CrossRef Medline

Wefelmeyer W, Puhl CJ, Burrone J (2016) Homeostatic plasticity of subcellular neuronal structures: from inputs to outputs. Trends Neurosci 39: 656-667. CrossRef Medline

Wimmer VC, Reid CA, So EY, Berkovic SF, Petrou S (2010) Axon initial segment dysfunction in epilepsy. J Physiol 588:1829-1840. CrossRef Medline

Winckler B, Forscher P, Mellman I (1999) A diffusion barrier maintains distribution of membrane proteins in polarized neurons. Nature 397: 698-701. CrossRef Medline

Xu K, Zhong G, Zhuang X (2013) Actin, spectrin, and associated proteins form a periodic cytoskeletal structure in axons. Science 339:452-456. CrossRef Medline

Xu M, Cooper EC (2015) An ankyrin-G N-terminal gate and protein kinase CK2 dually regulate binding of voltage-gated sodium and KCNQ2/3 potassium channels. J Biol Chem 290:16619-16632. CrossRef Medline

Xu X, Shrager P (2005) Dependence of axon initial segment formation on $\mathrm{Na}^{+}$channel expression. J Neurosci Res 79:428-441. CrossRef Medline

Yamada R, Kuba H (2016) Structural and functional plasticity at the axon initial segment. Front Cell Neurosci 10:255. CrossRef Medline

Yang S, Ben-Shalom R, Ahn M, Liptak AT, van Rijn RM, Whistler JL, Bender KJ (2016) $\beta$-Arrestin-dependent dopaminergic regulation of calcium channel activity in the axon initial segment. Cell Rep 16:1518-1526. CrossRef Medline

Yang Y, Ogawa Y, Hedstrom KL, Rasband MN (2007) betaIV spectrin is recruited to axon initial segments and nodes of Ranvier by ankyrinG. J Cell Biol 176:509-519. CrossRef Medline

Yau KW, van Beuningen SF, Cunha-Ferreira I, Cloin BM, van Battum EY, Will L, Schätzle P, Tas RP, van Krugten J, Katrukha EA, Jiang K, Wulf PS, Mikhaylova M, Harterink M, Pasterkamp RJ, Akhmanova A, Kapitein LC, Hoogenraad CC (2014) Microtubule minus-end binding protein CAMSAP2 controls axon specification and dendrite development. Neuron 82: 1058-1073. CrossRef Medline

Yau KW, Schätzle P, Tortosa E, Pagès S, Holtmaat A, Kapitein LC, Hoogenraad CC (2016) Dendrites in vitro and in vivo contain microtubules of opposite polarity and axon formation correlates with uniform plus-endout microtubule orientation. J Neurosci 36:1071-1085. CrossRef Medline

Yin L, Rasch MJ, He Q, Wu S, Dou F, Shu Y (2017) Selective modulation of axonal sodium channel subtypes by 5 -HT1A receptor in cortical pyramidal neuron. Cereb Cortex 27:509-521. CrossRef Medline

Yoshimura T, Rasband MN (2014) Axon initial segments: diverse and dynamic neuronal compartments. Curr Opin Neurobiol 27C:96-102. CrossRef Medline

Yoshimura T, Stevens SR, Leterrier C, Stankewich MC, Rasband MN (2016) Developmental changes in expression of $\beta \mathrm{IV}$ spectrin splice variants at axon initial segments and nodes of Ranvier. Front Cell Neurosci 10:304. CrossRef Medline

Zempel H, Dennissen FJ, Kumar Y, Luedtke J, Biernat J, Mandelkow EM, Mandelkow E (2017) Axodendritic sorting and pathological missorting of tau are isoform-specific and determined by axon initial segment architecture. J Biol Chem 292:12192-12207. CrossRef Medline

Zhang C, Rasband MN (2016) Cytoskeletal control of axon domain assembly and function. Curr Opin Neurobiol 39:116-121. CrossRef Medline

Zhang Y, Abiraman K, Li H, Pierce DM, Tzingounis AV, Lykotrafitis G (2017) Modeling of the axon membrane skeleton structure and implications for its mechanical properties. PLoS Comput Biol 13:e1005407. CrossRef Medline

Zhong G, He J, Zhou R, Lorenzo D, Babcock HP, Bennett V, Zhuang X (2014) Developmental mechanism of the periodic membrane skeleton in axons. Elife 3:194. CrossRef Medline

Zhou D, Lambert S, Malen PL, Carpenter S, Boland LM, Bennett V (1998) AnkyrinG is required for clustering of voltage-gated Na channels at axon initial segments and for normal action potential firing. J Cell Biol 143: 1295-1304. CrossRef Medline

Zhu S, Cordner ZA, Xiong J, Chiu CT, Artola A, Zuo Y, Nelson AD, Kim TY, Zaika N, Woolums BM, Hess EJ, Wang X, Chuang DM, Pletnikov MM, Jenkins PM, Tamashiro KL, Ross CA (2017) Genetic disruption of ankyrin- $\mathrm{G}$ in adult mouse forebrain causes cortical synapse alteration and behavior reminiscent of bipolar disorder. Proc Natl Acad Sci U S A 114: 10479-10484. CrossRef Medline

Zonta B, Desmazieres A, Rinaldi A, Tait S, Sherman DL, Nolan MF, Brophy PJ (2011) A critical role for neurofascin in regulating action potential initiation through maintenance of the axon initial segment. Neuron 69:945956. CrossRef Medline 